\title{
What Happens to Contraceptive Use After Injectables Are Introduced? An Analysis of 13 Countries
}

\section{By Elizabeth $G$. Sutherland, Conrad Otterness and Barbara Janowitz}

Elizabeth G.

Sutherland is research associate, Measure Evaluation Project, Carolina Population Center, University of North Carolina, Chapel Hill, NC, USA. Conrad Otterness is research associate, and Barbara Janowitz is senior technical advisor for program sciences, both with FHI360, Research Triangle Park, NC, USA.

\begin{abstract}
CONTEXT: Although the introduction of a new method is generally hailed as a boon to contraceptive prevalence, uptake of new methods can reduce the use of existing methods. It is important to examine changing patterns of contraceptive use and method mix after the introduction of new methods.
\end{abstract}

\begin{abstract}
METHODS: Demographic and Health Survey data from 13 countries were used to analyze changes in method use and method mix after the introduction of the injectable in the early 1990s. Subgroup analyses were conducted among married women who reported wanting more children, but not in the next two years (spacers), and those who reported wanting no more children (limiters).
\end{abstract}

RESULTS: Modern method use and injectable use rose for each study country. Increases in modern method use exceeded those in injectable use in all but three countries. Injectable use rose among spacers, as well as among limiters of all ages, particularly those younger than 35. In general, the increase in injectable use was partially offset by declines in use of other methods, especially long-acting or permanent methods.

CONCLUSION: Family planning programs could face higher costs and women could experience more unintended pregnancies if limiters use injectables for long periods, rather than changing to longer acting and permanent methods, which provide greater contraceptive efficacy at lower cost, when they are sure they want no more children. International Perspectives on Sexual and Reproductive Health, 2011,37(4):202-208, doi: 10.1363/3720211

The introduction of a new contraceptive method can affect patterns of contraceptive behavior, including method choice, which in turn can affect method mix and contraceptive prevalence. For example, a new method might attract women who otherwise would not practice contraception, leading to an increase in overall use. According to a study by Jain of the relationship between method availability and contraceptive prevalence in 72 countries in 1982, the widespread introduction of a new contraceptive method could increase total contraceptive prevalence by as much as 12 percentage points. ${ }^{1}$ However, a new contraceptive method could also draw current users away from other available methods. This possibility is a concern from a public health and program perspective if the new method replaces existing methods that are more effective, have higher continuation rates or are less expensive. How much a new method adds to total use or substitutes for other methods has not been well documented. ${ }^{2}$

Use of injectable hormonal contraceptives has risen rapidly in many countries. ${ }^{3}$ The injectable's widespread introduction into family planning programs worldwide followed the approval of Depo Provera (depot medroxyprogesterone acetate; DMPA) by the United States Food and Drug Administration in 1992. From 1995 to 2005, the estimated number of injectable users more than doubled, to more than 32 million; by 2015, as many as 40 million women are expected to be using the method.

The injectable has many benefits, which help explain its widespread popularity. From the perspective of users, it is more convenient than the pill or coitus-dependent methods: Whereas the pill needs to be taken every day and condoms need to be used at each act of intercourse to be effective, injections of DMPA-the main injectable in use-are needed only every three months. Also, unlike many estrogen-containing contraceptive pills, progestin-only injectables are appropriate for lactating women, so they can be used earlier in the postpartum period. ${ }^{2}$ Moreover, the injectable can be used discreetly by women who do not wish their partners to know that they are practicing contraception. ${ }^{3,4}$ And for women who are not yet ready for a permanent method, the injectable may be an attractive alternative to the IUD or implant. From the perspective of busy providers, injectables may offer advantages over long-acting reversible methods, such as implants or the IUD, which require a pelvic exam as well as special skills for insertion or removal; ${ }^{5}$ injectables can be administered by doctors and nurses, and also by providers with less medical education and medical training, such as community health workers. ${ }^{6}$

The introduction of the injectable could result in a net increase in contraceptive use. However, adoption of the injectable could replace use of more effective, less expensive long-acting and permanent methods, especially among women who wish to longer delay or permanently avoid future births. ${ }^{7}$ Such a substitution could be so great that a single method might dominate a country's method mix, regardless of the age or fertility intentions of contraceptive 
users. ${ }^{8}$ If programs reacted to this situation by stocking only the most popular methods, women's ability to choose from a range of effective methods could be greatly diminished.

In this article, we document recent global trends in use of the injectable and other modern methods. Because we hypothesize that trends in contraceptive use could be affected by changing fertility preferences and motivations, we consider women's desires for the timing and spacing of additional children-building on the work of Seiber et al. ${ }^{9}$ We also build on the study by Jain, ${ }^{1}$ by determining whether the potential gains that he estimated in contraceptive prevalence have been realized by the introduction of the injectable. Further, we examine whether the use of other methods has declined as injectable use has risen, and if so, which methods have seen the greatest changes in use.

\section{METHODS}

Data for this analysis were drawn from Demographic and Health Surveys (DHS). We included countries that had had two or more surveys since the introduction of the injectable in the early 1990s, modern contraceptive prevalence of at least $20 \%$ in the most recent survey and at least a five-percentage-point increase in injectable use between the early 1990s and the most recent survey. These criteria were selected to focus the analysis on the countries on which the injectable might have had the greatest impact in terms of contraceptive use outcomes. Thirteen countries, representing a variety of world regions, met the selection criteria: Bolivia, Egypt, Haiti, Indonesia, Kenya, Malawi, Namibia, Nepal, Nicaragua, Peru, Tanzania, Zambia and Zimbabwe. For the purposes of this study, we refer to the first survey in each country within the study period as the baseline and the most recent survey as the endline.

Because some surveys did not interview single women, our analysis was restricted to women in union, to make comparisons across countries easier. All analyses were conducted individually by country and survey year to appropriately account for survey weights.

Descriptive analyses were used to examine trends in contraceptive use and method mix. Method mix was restricted to modern methods, including injectables, other short-acting hormonal methods (e.g., the pill), barrier methods, the Standard Days method and the lactational amenorrhea method, as well as such permanent or longacting methods as male and female sterilization, the IUD and the implant.

We categorized potential contraceptive users as either "spacers" (those who reported wanting more children, but not for at least two years) or "limiters" (those who reported not wanting any more children); women not interested in spacing or limiting their childbearing were excluded. In some analyses, we stratified limiters by age, because method choice may be affected by the strength of women's motivation to avoid having additional children, which may vary by age and the closely correlated variable, number of living children. We used age 35 to divide younger and older limiters, because it was the approximate mean age of limiters in the 13 study countries over the study period (range, 33-39 years). Older age may be a proxy for strength of motivation to end childbearing. Furthermore, there is less time for an older limiter to change her desires before she becomes infecund.

Changes in contraceptive use were categorized as positive or negative if the value of the contraceptive use variable increased or decreased by more than one percentage point. In this way, spurious or small changes in use of contraceptives were not considered. We considered the injectable to have dominated changes in modern method use if its use accounted for $50 \%$ or more of the change in use of all modern methods.

\section{RESULTS}

\section{Overall Trends in Contraceptive Use}

Overall, the prevalence rates for the injectable and for any modern method ranged widely by country and over time (Table 1, page 204). In each country, injectable use and modern method use increased over the study period.

At baseline, injectable use was low in most countries; four countries-Bolivia, Egypt, Tanzania and Zambia-had initial injectable prevalence rates of no more than 1\%. Exceptions included Indonesia, Kenya and Namibia, which had baseline injectable prevalence of more than 5\%. At endline, injectable prevalence was lower than $10 \%$ in only four countries.

Overall modern method use also varied substantially. The lowest baseline rates were in Haiti, Malawi, Tanzania and Zambia (7-13\%), whereas the highest were in Egypt, Indonesia, Nicaragua and Zimbabwe (42-57\%). By endline, only three countries had modern method prevalence lower than $30 \%$.

The importance of the injectable in countries' method mix varied greatly. For the nine countries in which at least $10 \%$ of women relied on the injectable, the method accounted for at least $40 \%$ of modern method use in five of those-Haiti, Indonesia, Kenya, Malawi and Namibia-at the time of the last survey (not shown); in the other four, the proportions ranged from $17 \%$ to $23 \%$.

Given our criteria for choosing countries, it is not surprising that the increase in injectable use from baseline to endline was substantial in most countries (Figure 1, page 205). The increase in injectable use varied from a low of five percentage points in Nepal to a high of 20 points in Indonesia. Modern method use increased by as little as five points in Kenya to as much as 27 points in Namibia. Nine countries experienced an increase in modern method use of at least 12 points, the amount predicted by Jain, ${ }^{1}$ and two others had an increase close to that. Increases in modern method use exceeded increases in injectable use in all but three countries: Indonesia and Kenya experienced greater increases in injectable use than in modern method use, while in Nicaragua, injectable use and modern method use increased by the same amount. In 10 countries, the increase in injectable use accounted for at least half of the change in modern method use. 


\begin{tabular}{|c|c|c|c|c|c|c|c|c|c|c|}
\hline \multirow[t]{2}{*}{ Country } & \multicolumn{2}{|c|}{ 1991-1993 } & \multicolumn{2}{|c|}{ 1994-1996 } & \multicolumn{2}{|c|}{ 1997-1999 } & \multicolumn{2}{|c|}{$2000-2003$} & \multicolumn{2}{|c|}{$2004-2007$} \\
\hline & DMPA & Any & DMPA & Any & DMPA & Any & DMPA & Any & DMPA & Any \\
\hline Bolivia & u & u & u & u & 1 & 25 & 8 & 35 & u & $\mathbf{u}$ \\
\hline Spacers & u & u & u & u & 2 & 33 & 9 & 41 & $\mathrm{u}$ & $\mathrm{u}$ \\
\hline Young limiters & u & u & u & u & 2 & 31 & 13 & 43 & $\mathrm{u}$ & $\mathrm{u}$ \\
\hline Older limiters & u & u & u & $\mathrm{u}$ & 1 & 35 & 6 & 42 & u & $\mathrm{u}$ \\
\hline Egypt & 1 & 45 & 2 & 46 & u & $\mathbf{u}$ & 6 & 54 & 7 & 57 \\
\hline Spacers & $<1$ & 48 & 2 & 53 & u & $\mathrm{u}$ & 5 & 70 & 5 & 69 \\
\hline Young limiters & $<1$ & 71 & 5 & 72 & u & u & 11 & 86 & 13 & 86 \\
\hline Older limiters & 1 & 75 & 4 & 75 & u & u & 10 & 81 & 11 & 87 \\
\hline Haiti & $\mathbf{u}$ & $\mathbf{u}$ & 3 & 13 & u & $\mathbf{u}$ & 12 & 23 & 11 & 25 \\
\hline Spacers & u & u & 5 & 18 & u & $\mathrm{u}$ & 15 & 29 & 14 & 34 \\
\hline Young limiters & u & u & 6 & 21 & u & u & 25 & 40 & 25 & 40 \\
\hline Older limiters & u & u & 2 & 22 & u & u & 11 & 29 & 10 & 31 \\
\hline Indonesia & 12 & 47 & 15 & 52 & 21 & 55 & 28 & 57 & 32 & 57 \\
\hline Spacers & 22 & 65 & 28 & 74 & 37 & 78 & 48 & 80 & 53 & 80 \\
\hline Young limiters & 21 & 80 & 26 & 82 & 36 & 84 & 46 & 84 & 54 & 85 \\
\hline Older limiters & 11 & 76 & 13 & 78 & 19 & 78 & 27 & 79 & 32 & 80 \\
\hline Kenya & 7 & 27 & u & $\mathbf{u}$ & 12 & 32 & 14 & 32 & $\mathbf{u}$ & $\mathbf{u}$ \\
\hline Spacers & 6 & 23 & u & u & 13 & 32 & 20 & 36 & $\mathrm{u}$ & $\mathrm{u}$ \\
\hline Young limiters & 17 & 55 & u & u & 28 & 59 & 29 & 54 & u & $\mathrm{u}$ \\
\hline Older limiters & 11 & 50 & u & u & 18 & 61 & 18 & 59 & u & $\mathrm{u}$ \\
\hline Malawi & 2 & 7 & $\mathbf{u}$ & $\mathbf{u}$ & $\mathbf{u}$ & $\mathbf{u}$ & 16 & 26 & 18 & 28 \\
\hline Spacers & 1 & 10 & u & u & u & $\mathrm{u}$ & 28 & 37 & 33 & 44 \\
\hline Young limiters & 2 & 18 & u & $\mathrm{u}$ & u & u & 30 & 44 & 31 & 50 \\
\hline Older limiters & 8 & 24 & u & u & u & u & 20 & 46 & 18 & 63 \\
\hline Namibia & 8 & 26 & $\mathbf{u}$ & $\mathbf{u}$ & $\mathbf{u}$ & $\mathbf{u}$ & 19 & 43 & 22 & 53 \\
\hline Spacers & 13 & 33 & u & $\mathrm{u}$ & u & $\mathrm{u}$ & 29 & 53 & 29 & 64 \\
\hline Young limiters & 25 & 70 & u & u & u & u & 36 & 67 & 40 & 73 \\
\hline Older limiters & 12 & 65 & u & u & u & u & 18 & 66 & 19 & 73 \\
\hline Nepal & $\mathbf{u}$ & $\mathbf{u}$ & 5 & 26 & $\mathbf{u}$ & $\mathbf{u}$ & 8 & 35 & 10 & 44 \\
\hline Spacers & u & u & 4 & 10 & u & u & 9 & 19 & 12 & 29 \\
\hline Young limiters & $\mathrm{u}$ & u & 11 & 52 & u & $\mathrm{u}$ & 16 & 59 & 16 & 65 \\
\hline Older limiters & u & u & 6 & 60 & $\mathrm{u}$ & u & 11 & 66 & 12 & 71 \\
\hline Nicaragua & $\mathbf{u}$ & $\mathbf{u}$ & u & u & 5 & 57 & 14 & 66 & u & $\mathbf{u}$ \\
\hline Spacers & $\mathrm{u}$ & u & u & $\mathrm{u}$ & 10 & 62 & 25 & 74 & $\mathrm{u}$ & $\mathrm{u}$ \\
\hline Young limiters & u & u & u & u & 7 & 78 & 20 & 81 & u & u \\
\hline Older limiters & u & u & u & $\mathrm{u}$ & 3 & 81 & 7 & 81 & u & $\mathrm{u}$ \\
\hline Peru & 2 & 33 & 8 & 41 & $\mathbf{u}$ & $\mathbf{u}$ & 15 & 50 & 11 & 47 \\
\hline Spacers & 3 & 37 & 11 & 47 & u & u & 22 & 57 & 15 & 54 \\
\hline Young limiters & 3 & 39 & 14 & 53 & u & u & 25 & 65 & 19 & 54 \\
\hline Older limiters & 2 & 43 & 4 & 50 & u & u & 8 & 61 & 9 & 60 \\
\hline Tanzania & $<1$ & 7 & 5 & 13 & 6 & 17 & $\mathbf{u}$ & $\mathbf{u}$ & 8 & 20 \\
\hline Spacers & $<1$ & 13 & 9 & 25 & 13 & 34 & $\mathrm{u}$ & $\mathrm{u}$ & 16 & 35 \\
\hline Young limiters & 3 & 20 & 12 & 37 & 13 & 41 & u & u & 22 & 48 \\
\hline Older limiters & 2 & 23 & 11 & 35 & 13 & 35 & u & u & 15 & 44 \\
\hline Zambia & $<1$ & 9 & 1 & 14 & u & $\mathbf{u}$ & 5 & 25 & 9 & 33 \\
\hline Spacers & $<1$ & 15 & 2 & 24 & $\mathrm{u}$ & $\mathrm{u}$ & 5 & 39 & 15 & 48 \\
\hline Young limiters & $<1$ & 25 & 3 & 37 & u & $\mathrm{u}$ & 12 & 48 & 13 & 52 \\
\hline Older limiters & $<1$ & 26 & 2 & 28 & u & u & 7 & 36 & 9 & 43 \\
\hline Zimbabwe & u & $\mathbf{u}$ & 3 & 42 & 8 & 50 & $\mathbf{u}$ & $\mathbf{u}$ & 10 & 58 \\
\hline Spacers & u & u & 3 & 63 & 8 & 74 & u & u & 10 & 79 \\
\hline Young limiters & u & u & 8 & 75 & 18 & 80 & u & $\mathrm{u}$ & 16 & 82 \\
\hline Older limiters & u & u & 7 & 57 & 16 & 67 & u & u & 17 & 76 \\
\hline
\end{tabular}

\section{Contraceptive Use Patterns by Subgroup}

The increase in injectable use in all countries except Zimbabwe was highest among spacers or younger limiters rather than among older limiters (Table 2, page 206); in six countries, the largest increases occurred among spacers (from eight percentage points in Nepal to 32 points in Malawi) and in six countries, among younger limiters (from 11 points in Nepal to 33 points in Indonesia). Even so, injectable use rose sharply among older limiters, from five points in Bolivia to 21 points in Indonesia. We found no 
evidence in most countries of a shift over time in the proportion of women overall classified as spacers or limiters that could confound any trends seen among these spacing groups (not shown); the exceptions were Malawi, Namibia and Zambia-all of which had increases in the proportion of all women classified as spacers or limiters, as well as an increase in the total classified in these groups.

When we examined changes in injectable use relative to changes in use of any modern method, no consistent pattern emerged (Table 3, page 207). The injectable was the dominant method-that is, the change in injectable use accounted for at least half of the change in all modern contraceptive use-in 10 countries (not shown). However, there was no pattern in the number of countries in which the injectable dominated the change in modern method use across subgroups: By adding the first three columns of each row, we can see that the injectable dominated the change among spacers in nine countries, among younger limiters in 11 countries and among older limiters in 10 countries. With a more stringent criterion for dominancethe change in injectable use exceeded or equaled the change in modern method use (first two columns only)again there is no apparent pattern in the number of countries by subgroup (four, eight and four, respectively). What does stand out is that of the 16 country combinations of dominance and desired pregnancy spacing (e.g., Indonesia/spacers), there is clearly clustering, with six of the combinations accounted for by Indonesia and Nicaragua, and two each by Bolivia, Haiti, Kenya and Namibia. These findings indicate that if injectables play a dominant role in one subgroup in a given country, they usually do so in at least one other group. Thus, injectables apparently play a fairly consistent role in affecting method use across all user subgroups, rather than having a different impact in the various spacing groups and, in general, have become the most commonly used method in each subgroup.

\section{Changes in the Use of Other Methods}

We next explore changes in the use of other contraceptive methods (Table 2). Among spacers, the proportion relying on short-acting methods other than the injectable increased in all countries except Indonesia and Kenya, and in four countries, the proportion using short-acting methods increased more than the proportion using injectables. In contrast, the proportion of spacers relying on long-acting and permanent methods increased in just one country (Egypt), decreased substantially in three countries (Indonesia, Nicaragua and Peru) and either remained stable or showed small declines in the remainder. Thus, it seems that since the introduction of the injectable, the proportion of spacers may have shifted from using long-acting methods to using injectables and other short-acting methods.

In general, the proportion of limiters relying on longacting or permanent methods also declined. In only four countries (Egypt, Malawi, Nepal and Tanzania) was there an increase over the study period in the proportion of limiters (younger, older or both) relying on long-acting and
FIGURE 1. Percentage point change between baseline and endline surveys in the proportion of currently married women using the injectable or any modern method, by country

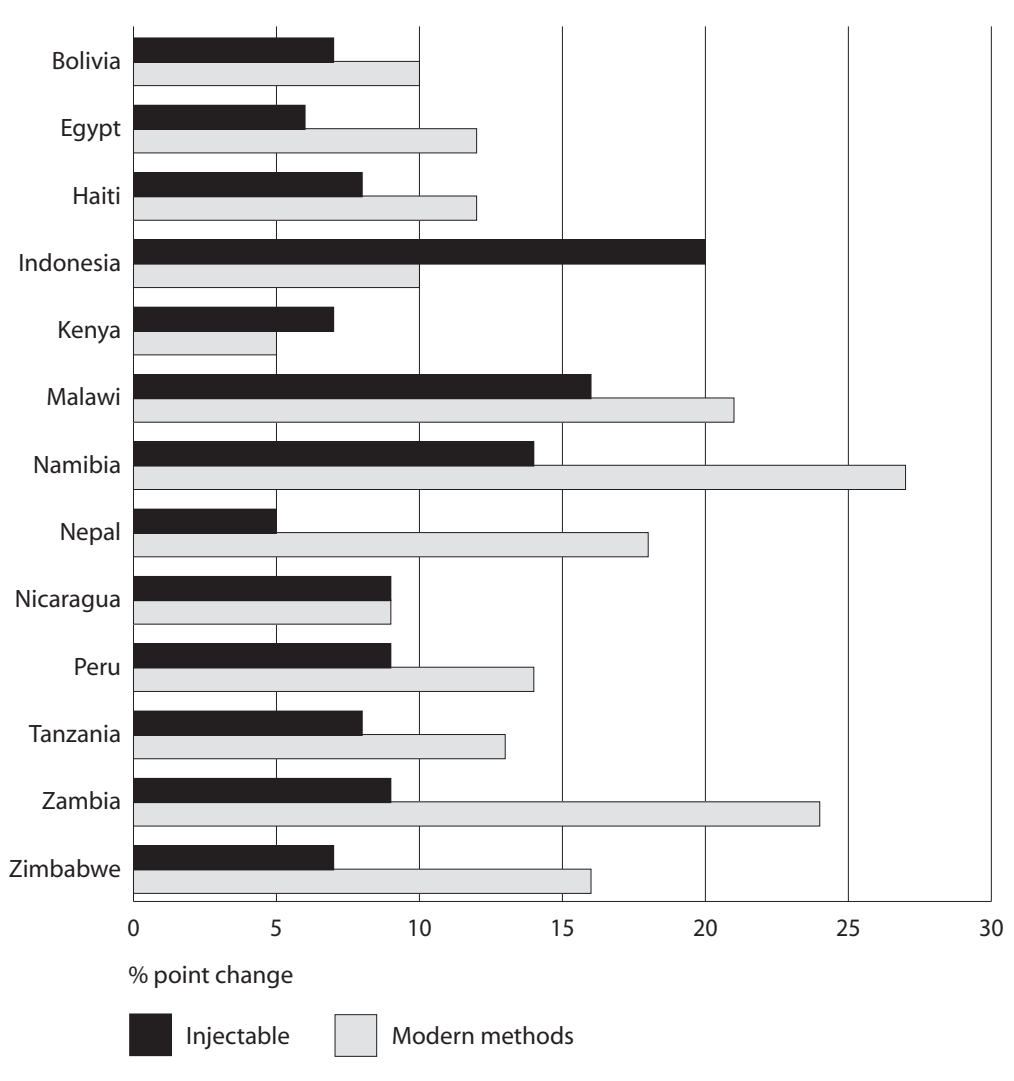

permanent methods. In contrast, use of short-acting methods other than the injectable increased among at least one group of limiters in 10 of the 13 study countries. Thus, even though limiters, by definition, want no more children, an increasing proportion of them used short-acting methods, especially injectables.

Among the countries in which use of long-acting and permanent methods decreased among some limiters, no one method dominated the decrease: Six countries experienced declines (of more than one percentage point) in sterilization and six experienced declines in IUD use (Table 4, page 207). The largest declines in sterilization occurred in Namibia and Zambia (nine and six points, respectively), with smaller declines in Haiti, Kenya, Nicaragua and Zimbabwe (3-5 points). Indonesia had the largest decrease in IUD prevalence (16 points), but IUD use also decreased in Bolivia, Kenya, Namibia, Nicaragua and Peru (2-8 points). For the two countries that had large increases in long-acting and permanent method prevalence, the methods that dominated that change differed: Egypt experienced an 11-point increase in IUD use, whereas Malawi experienced a 10-point increase in reliance on sterilization.

\section{Sample Cases: Indonesia and Malawi}

Two case studies-Indonesia and Malawi-illustrate our finding that countries can experience increases in injectable use with different changes in overall contraceptive use and 
TABLE 2. Percentage of women in union using contraceptive methods, by type of method used at first and last survey, according to country and subgroup

\begin{tabular}{|c|c|c|c|c|c|c|}
\hline \multirow[t]{2}{*}{ Country (survey period) } & \multicolumn{2}{|c|}{ Injectable } & \multicolumn{2}{|c|}{$\begin{array}{l}\text { Other } \\
\text { short-acting }\end{array}$} & \multicolumn{2}{|c|}{$\begin{array}{l}\text { Long-acting/ } \\
\text { permanent }\end{array}$} \\
\hline & First & Last & First & Last & First & Last \\
\hline \multicolumn{7}{|l|}{ Bolivia (1998-2003) } \\
\hline Spacers & 2 & 9 & 13 & 14 & 18 & 17 \\
\hline Younger limiters & 2 & 13 & 10 & 13 & 20 & 16 \\
\hline Older limiters & 1 & 6 & 4 & 9 & 30 & 27 \\
\hline \multicolumn{7}{|l|}{ Egypt (1992-2005) } \\
\hline Spacers & $<1$ & 5 & 13 & 16 & 35 & 48 \\
\hline Younger limiters & $<1$ & 13 & 23 & 15 & 45 & 55 \\
\hline Older limiters & 1 & 11 & 26 & 15 & 43 & 58 \\
\hline \multicolumn{7}{|l|}{ Haiti (1994-2006) } \\
\hline Spacers & 5 & 14 & 10 & 19 & 2 & 1 \\
\hline Younger limiters & 6 & 25 & 9 & 11 & 7 & 4 \\
\hline Older limiters & 2 & 10 & 7 & 10 & 14 & 12 \\
\hline \multicolumn{7}{|l|}{ Indonesia (1991-1997) } \\
\hline Spacers & 22 & 53 & 26 & 20 & 18 & 7 \\
\hline Younger limiters & 21 & 54 & 24 & 20 & 34 & 11 \\
\hline Older limiters & 11 & 32 & 22 & 22 & 43 & 27 \\
\hline \multicolumn{7}{|l|}{ Kenya (1993-2003) } \\
\hline Spacers & 6 & 20 & 14 & 12 & 4 & 4 \\
\hline Younger limiters & 17 & 29 & 23 & 17 & 15 & 9 \\
\hline Older limiters & 11 & 18 & 9 & 13 & 30 & 28 \\
\hline \multicolumn{7}{|l|}{ Malawi (1992-2004) } \\
\hline Spacers & 1 & 33 & 8 & 11 & 1 & 1 \\
\hline Younger limiters & 2 & 31 & 8 & 5 & 8 & 10 \\
\hline Older limiters & 8 & 18 & 5 & 3 & 11 & 33 \\
\hline \multicolumn{7}{|l|}{ Namibia (1992-2007) } \\
\hline Spacers & 13 & 29 & 17 & 33 & 3 & 1 \\
\hline Younger limiters & 25 & 40 & 22 & 25 & 23 & 8 \\
\hline Older limiters & 12 & 19 & 11 & 19 & 42 & 35 \\
\hline \multicolumn{7}{|l|}{ Nepal (1996-2006) } \\
\hline Spacers & 4 & 12 & 5 & 16 & 1 & 1 \\
\hline Younger limiters & 11 & 16 & 7 & 14 & 35 & 35 \\
\hline Older limiters & 6 & 12 & 4 & 6 & 50 & 54 \\
\hline \multicolumn{7}{|l|}{ Nicaragua (1997-2001) } \\
\hline Spacers & 10 & 25 & 33 & 38 & 19 & 11 \\
\hline Younger limiters & 7 & 20 & 21 & 24 & 50 & 38 \\
\hline Older limiters & 3 & 7 & 11 & 11 & 68 & 63 \\
\hline \multicolumn{7}{|l|}{ Peru (1992-2008) } \\
\hline Spacers & 3 & 15 & 14 & 28 & 20 & 11 \\
\hline Younger limiters & 3 & 19 & 13 & 18 & 23 & 16 \\
\hline Older limiters & 2 & 9 & 9 & 17 & 33 & 34 \\
\hline \multicolumn{7}{|l|}{ Tanzania (1992-2004) } \\
\hline Spacers & $<1$ & 16 & 11 & 17 & 1 & 2 \\
\hline Younger limiters & 3 & 22 & 11 & 18 & 7 & 9 \\
\hline Older limiters & 2 & 15 & 6 & 10 & 15 & 19 \\
\hline \multicolumn{7}{|l|}{ Zambia (1992-2007) } \\
\hline Spacers & $<1$ & 15 & 14 & 34 & 1 & $<1$ \\
\hline Younger limiters & $<1$ & 13 & 18 & 37 & 8 & 3 \\
\hline Older limiters & $<1$ & 9 & 9 & 24 & 17 & 11 \\
\hline \multicolumn{7}{|l|}{ Zimbabwe (1994-2006) } \\
\hline Spacer & 3 & 10 & 59 & 67 & 1 & 2 \\
\hline Younger limiters & 8 & 16 & 60 & 61 & 8 & 5 \\
\hline Older limiters & 7 & 17 & 37 & 46 & 13 & 13 \\
\hline
\end{tabular}

Notes: Spacers were women who reported wanting more children, but not in the next two years. Limiters were women who reported not wanting any more children. Younger limiters were those younger than 35 ; older limiters were 35 or older. in modern method use was smaller than the increase in injectable use for all three subgroups. On the other hand, in Malawi, injectables dominated the change in modern method mix among spacers and younger limiters only, but by a smaller proportion than in Indonesia.

The differences in the changes in method use between the two countries are particularly striking with respect to long-acting and permanent methods. In Indonesia, use of such methods decreased among all three contraceptive subgroups: eleven percentage points among spacers, and 23 points and 16 points among younger and older limiters, respectively (Table 2). In Malawi, however, use of long-acting and permanent methods did not decrease in any subgroup, and in fact increased among both younger and older limiters (two points and 22 points, respectively). When we looked at changes in use of specific longacting and permanent methods use among limiters, Malawi's biggest change was a 10-point increase in sterilization use, whereas the biggest change in Indonesia was a 16-point decrease in IUD use (Table 4).

\section{DISCUSSION}

Nine of the countries included in this study experienced an increase in modern method use of at least 12 percentage points following the widespread introduction of the injectable-giving support to Jain's predictions; ${ }^{1}$ two other countries had increases almost that large. Other countries, however, experienced smaller changes in modern method use, especially among particular subgroups of users. In the vast majority of cases, the change in method mix was dominated by increasing use of injectables.

It is, of course, the overall changes in method mix, rather than changes in the use of a single method, that are of critical importance to setting policy and program priorities in low-resource settings, ${ }^{9}$ and understanding changes in method mix requires analysis of subgroups of spacers and limiters. Our analysis demonstrates that long-acting and permanent method use decreased in many countriesparticularly among limiters-as injectable use increased. Changes in the method mix used by limiters were similar to those for spacers, whose reliance on short-acting methods, including the injectable, increased over time. However, many spacers may have chosen to rely on the injectable and other short-acting methods because the IUD may have been the only reversible long-acting method available.

Younger limiters who are not yet ready to make a final decision to not have another child may face method choices as restricted as women who want to delay their next birth. Older limiters who feel certain that they do not want more children could, perhaps, more comfortably select IUDs or sterilization; nevertheless, adoption of longacting and permanent methods in this group declined in most countries. This decline could be a concern from a programmatic perspective, if it were associated with higher contraceptive discontinuation rates or a higher incidence of unintended pregnancy. 
Differences in method mix trends have cost implications for family planning programs. Our results for Indonesia and Malawi illustrate this point. In Indonesia, the proportion of limiters relying on injectables rose as the proportion using long-acting and permanent methods declined. Meanwhile, in Malawi, the proportion of limiters relying on long-acting methods and the proportion using injectables both increased. All else being equal, in areas where limiters tend to adopt relatively inexpensive, long-acting or permanent methods at fairly young ages, continuation rates would be higher and contraceptive costs would be lower than in areas where such limiters rely on the injectable or other moreexpensive, short-acting methods.

Increasing availability of contraceptive implants or development of new or less-expensive options, particularly in long-acting reversible methods, would widen contraceptive choices and could reduce contraceptive costs for country programs. Although many implants are costly, perhaps even more costly than injectables if used for a short period of time, a low-cost implant such as the one recently registered in Kenya could prove to be a more cost-effective alternative to injectables, even if used for short periods of time. ${ }^{10}$

Although the importance of the injectable in the method mix raises potential programmatic concerns, especially for limiters, it is important to recognize the positive impacts of the introduction of the method. Overall contraceptive use increased in all 13 countries we examined, and increased by at least 10 percentage points in 11 of those. The injectable, by increasing women's choices and providing an alternative to methods that are coitusdependent or must be taken daily, likely contributed to this gain-particularly in countries that had very low contraceptive use only $10-15$ years ago.

\section{Limitations}

This study has several limitations. Although our results indicate that long-acting and permanent method use declined in most countries after the introduction of the injectable, we cannot definitively conclude that the popularity of the new method was the cause. The decrease could be explained by a host of other program and policy concerns that could include the shifting of funds from family planning to other public health priorities or increased attention to emerging family planning priorities, such as method provision for youth, lengthened interval between marriage and a first birth for newlyweds or the use of barrier methods for dual protection against pregnancy and STI prevention for individuals with risky sexual behavior-all of which are unlikely.

An additional limitation was that all analyses were restricted to the years in which data were collected in each country, and the length of time between the first and last survey varied widely across countries. Further, it is impossible to determine whether the time period for which data were available best captures the period in which injectable use increased. In fact, the trends described in this paper may be in flux.
TABLE 3. Distribution of countries, by comparisons between percentage point changes in injectable use and in any modern method use, according to subgroup

\begin{tabular}{|c|c|c|c|c|}
\hline \multirow[t]{2}{*}{ Category } & \multicolumn{3}{|c|}{ DMPA dominates } & \multirow{2}{*}{$\begin{array}{l}\begin{array}{l}\text { DMPA does } \\
\text { not dominate }\end{array} \\
\begin{array}{l}\text { DMPA/any } \\
<0.5\end{array}\end{array}$} \\
\hline & $\begin{array}{l}\text { DMPA/any } \\
>1.0\end{array}$ & $\begin{array}{l}\text { DMPA/any } \\
=1.0\end{array}$ & $\begin{array}{l}\text { DMPA/any } \\
=0.5-0.99\end{array}$ & \\
\hline Spacers & $\begin{array}{l}2 \text { (Indonesia, } \\
\text { Nicaragua) }\end{array}$ & $\begin{array}{l}2 \text { (Bolivia, } \\
\text { Kenya) }\end{array}$ & $\begin{array}{l}5 \text { (Haiti,Malawi, } \\
\text { Namibia, Peru, } \\
\text { Tanzania) }\end{array}$ & $\begin{array}{l}4 \text { (Egypt, Nepal, } \\
\text { Zambia, } \\
\text { Zimbabwe) }\end{array}$ \\
\hline Younger limiters & $\begin{array}{l}4 \text { (Indonesia, } \\
\text { Kenya, } \\
\text { Namibia, } \\
\text { icaragua) }\end{array}$ & $\begin{array}{l}4 \text { (Bolivia, } \\
\text { Haiti,Peru, } \\
\text { Zimbabwe) }\end{array}$ & $\begin{array}{l}3 \text { (Egypt, Malawi, } \\
\text { Tanzania) }\end{array}$ & $\begin{array}{l}2 \text { (Nepal, } \\
\text { Zambia) }\end{array}$ \\
\hline Older limiters & $\begin{array}{l}2 \text { (Indonesia, } \\
\text { Nicaragua) }\end{array}$ & $\begin{array}{l}2 \text { (Haiti, } \\
\text { Namibia) }\end{array}$ & $\begin{array}{l}6 \text { (Bolivia, Egypt, } \\
\text { Kenya, Nepal, } \\
\text { Tanzania,Zimbabwe) }\end{array}$ & $\begin{array}{l}3 \text { (Malawi, Peru, } \\
\text { Zambia) }\end{array}$ \\
\hline Total & 8 & 8 & 14 & 9 \\
\hline
\end{tabular}

Notes: DMPA=the injectable (depot medroxyprogesterone acetate). The injectable was considered to have dominated a country's change in modern method use if its use accounted for at least $50 \%$ of the change in use of any modern methods. Spacers were women who reported wanting more children, but not in the next two years. Limiters were women who reported not wanting any more children. Younger limiters were those younger than 35; older limiters were 35 or older.

\section{CONCLUSIONS}

From a program perspective, more emphasis on long-acting and permanent method provision might lead to greater prevention of unintended pregnancy and lower costs; however, such emphasis should not be at the expense of women's method choices to meet their goals for both spacing and limiting. Ideally, women would progress from shorter- to longer-acting methods, and finally to a permanent method when they were sure that they would not want more children. As a result, unplanned pregnancies would decrease and the costs of providing contraception would decline. Instead, according to our analysis, the opposite may have occurred in some of our study countries: Costly short-acting methods (especially the injectable) have become more widely used, regardless of age and fertility intention.

Despite dramatic increases in family planning, about one in six married women continue to have an unmet need. Given the decrease in donor funds for contraception as funds have been reallocated to HIV and AIDS pro-

\begin{tabular}{|c|c|c|c|}
\hline Country & Sterilization & IUD & Implant \\
\hline Bolivia & -1 & -3 & 0 \\
\hline Egypt & 0 & 11 & 1 \\
\hline Haiti & -3 & 0 & 1 \\
\hline Indonesia & -1 & -16 & -1 \\
\hline Kenya & -3 & -3 & 3 \\
\hline Malawi & 10 & -1 & 1 \\
\hline Namibia & -9 & -2 & 0 \\
\hline Nepal & 1 & 1 & 0 \\
\hline Nicaragua & -5 & -3 & 0 \\
\hline Peru & 6 & -8 & 0 \\
\hline Tanzania & 3 & -1 & 1 \\
\hline Zambia & -6 & -1 & 1 \\
\hline Zimbabwe & -3 & -1 & 2 \\
\hline
\end{tabular}


grams, ${ }^{11}$ countries may need to emphasize a cost-effective method mix. A combination of interventions may be needed to foster demand and to promote and provide longeracting and permanent methods to women for whom they are appropriate. Strategies for how such changes can be made and sustained by family planning programs need to be developed and tested as part of the continuing contraceptive research agenda.

\section{REFERENCES}

1. Jain AK, Fertility reduction and the quality of family planning services, Studies in Family Planning, 1989, 20(1):1-16.

2. Gray AL et al., Systematic Review of Contraceptive Medicines: Does Choice Make a Difference? Johannesburg, South Africa: University of the Witwatersrand, 2006, <http://www.k4health.org/system/files/ 311684.pdf>, Nov. 15, 2011.

3. Lande $\mathrm{R}$ and Richey $\mathrm{C}$, Expanding services for injectables, Population Reports, 2006, Series K, No. 6.

4. Adetunji J, Rising popularity of injectable contraception in SubSaharan Africa, paper presented at the annual meeting of the Population Association of America, Mar. 30-Apr. 1, 2010, Los Angeles, CA.

5. Stanback J, Odhiambo O and Omundo D, Why Has Intrauterine Device Use Slowed in Kenya? Part A. Qualitative Assessment of Intrauterine Device Service Delivery in Kenya, Research Triangle Park, NC, USA: Family Health International, 1995.

6. Malarcher S et al., Provision of DMPA by community health workers: what the evidence shows, Contraception, 2011, 83(6):495-503.

7. Trussell J et al., The economic value of contraception: a comparison of 15 methods, American Journal of Public Health, 1995, 85(4):494- 503.

8. Sullivan TM et al., Skewed contraceptive method mix: why it happens, why it matters, Journal of Biosocial Science, 2006, 38(4):501-521.

9. Seiber EE, Bertrand JT and Sullivan T, Changes in contraceptive method mix in developing countries, International Family Planning Perspectives, 2007, 33(3):117-123.

10. Tumlinson K et al., Promise of affordable implants: Is cost recovery possible in Kenya? Contraception, 2011, 83(1):88-93.

11. Kols A, Reducing unmet need for family planning: evidence-based strategies and approaches, Outlook, 2008, 25(1):1-8

\section{RESUMEN}

Contexto: Aunque la introducción de un nuevo método se recibe generalmente como algo muy positivo para la prevalencia del uso de anticonceptivos, la aceptación de un nuevo método puede reducir el uso de los métodos existentes. Es importante examinar cómo un nuevo método cambia los patrones del uso y la combinación de métodos usados.

Métodos: Se usaron datos de las Encuestas Demográficas y de Salud de 13 países, desde los años noventa hasta fechas recientes, para analizar cambios en el uso de métodos y la combinación de métodos posteriores a la introducción de los inyectables a principios de los años noventa. Se realizó análisis de mujeres casadas según sus preferencias de fecundidad: las que deseaban tener más hijos pero no en los próximos dos años (buscaban espaciar sus hijos); y las que no deseaban tener más hijos (buscaban limitar el número de hijos).

Resultados: El uso de métodos modernos, y del método moderno individual del inyectable, aumentó en cada país del estudio. Los aumentos en el uso de métodos modernos en total excedieron los aumentos en el uso del inyectable en todos los países con excepción de tres. El uso del inyectable aumentó entre las mujeres de todas las edades que querían espaciar los nacimientos; así como entre todas las que querían dejar de procrear, pero especialmente en las menores de 35 años de estas últimas. En general, el aumento en el uso del inyectable se compensó parcialmente por disminuciones en el uso de otros métodos, especialmente los de larga duración o permanentes.

Conclusión: Los programas de planificación familiar podrían enfrentar costos mayores, y las mujeres podrían tener más embarazos no planeados, si las que quieren dejar de procrear usan los inyectables por períodos largos en lugar de cambiar a métodos de larga duración y métodos permanentes. Es decir cuando las mujeres están seguras de que no desean más hijos, los métodos permanentes y los de larga duración proporcionan una mayor eficacia anticonceptiva a menor costo.

\section{RÉSUMÉ}

Contexte: Bien que l'introduction d'une nouvelle méthode soit généralement saluée comme une aubaine pour la prévalence contraceptive, l'adoption de nouvelles méthodes peut réduire la pratique de celles existantes. Il importe d'examiner les tendances changeantes de la pratique contraceptive et de l'éventail de méthodes après l'introduction de nouveaux choix.

Méthodes: Les données d'EDS de 13 pays ont servi à analyser les changements de pratique et d'éventail de méthodes après l'introduction de l'injectable au début des années 1990. Des analyses de sous-groupes ont été menées parmi les femmes mariées ayant déclaré désirer avoir encore des enfants mais pas durant les deux prochaines années (désir d'espacement) et celles ayant déclaré ne plus vouloir d'enfants (désir de limitation).

Résultats: La pratique des méthodes modernes et celle de l'injectable ont augmenté dans chaque pays soumis à l'étude. La hausse de la pratique des méthodes modernes dépasse celle du choix de l'injectable dans tous les pays sauf trois. La pratique de l'injectable a augmenté parmi les femmes désireuses d'espacer leurs grossesses tout comme parmi celles désireuses de les limiter à tous âges, en particulier avant l'âge de 35 ans. En général, la hausse de la pratique de l'injectable est partiellement compensée par la baisse enregistrée au niveau d'autres méthodes, de longue durée ou permanentes surtout.

Conclusion: Les programmes de planification familiale pourraient se trouver confrontés à des coûts supérieurs et les femmes à de plus grands nombres de grossesses non planifiées si celles désireuses de limiter leurs naissances recourent aux injectables à long terme, plutôt que de passer aux méthodes longue durée ou permanentes qui leur assureraient une plus grande efficacité contraceptive à moindre coût lorsqu'elles sont sûres de ne plus vouloir d'enfants.

\section{Acknowledgments}

This work was completed with support from the United States Agency for International Development to FHI360 (Family Health International) under cooperative agreement GPO-A-00-05-0002200 while the first author was affiliated with FHI360 (Family Health International), and subsequently under cooperative agreement GPO-A-00-08-00001-00 to the additional authors. The views expressed in this article are solely those of the authors.

Authorcontact:beth_sutherland@unc.edu 